\title{
Nimotuzumab enhances the sensitivity of non-small cell lung cancer cells to tumor necrosis factor- $\alpha$ by inhibiting the nuclear factor-кB signaling pathway
}

\author{
JING ZHU $^{1 *}$, YING XIN $^{1 *}$, XIAOLIANG LIU ${ }^{2}$, YING WANG $^{1}$ and YING LIU ${ }^{1}$ \\ ${ }^{1}$ Department of Thoracic Oncology, Cancer Hospital of Jilin Province, Changchun, Jilin 130012; \\ ${ }^{2}$ Department of Blood Cancer, The First Affiliated Hospital of Jilin University, Changchun, Jilin 130021, P.R. China
}

Received September 25, 2017; Accepted December 6, 2017

DOI: $10.3892 /$ etm.2018.5856

\begin{abstract}
Non-small cell lung cancer (NSCLC) accounts for $\sim 85 \%$ of lung cancer cases worldwide. Current guidelines recommend the use of epidermal growth factor receptor (EGFR) tyrosine kinase inhibitors for patients with NSCLC. The EGF/EGFR signaling pathway has been demonstrated to activate nuclear factor $(\mathrm{NF})-\kappa \mathrm{B}$, which may inhibit tumor necrosis factor (TNF)- $\alpha$ induced cell apoptosis. The aim of the present study was to investigate whether inhibiting the EGF/EGFR signaling pathway sensitizes NSCLC cell lines to TNF- $\alpha$-induced apoptosis. The resistance of NSCLC cell lines to TNF- $\alpha$ was evaluated by cell viability assay. The effect of nimotuzumab (Ni) on NSCLC cell sensitivity to TNF- $\alpha$, as well as the role of NF- $\kappa \mathrm{B}$ in mediating resistance to TNF- $\alpha$-induced apoptosis, was explored by western blot analysis, cell viability assay, apoptosis assay and an NF- $\kappa \mathrm{B}$ DNA binding assay. It was demonstrated that EGFR protein expression was markedly higher in the H292 and H1975 cell lines compared with H460 and H1299 cell lines. H292 and H1975 also exhibited significantly increased TNF- $\alpha$ resistance compared with $\mathrm{H} 460$ and H1299 cells. Low dose Ni treatment slightly reduced the viability of H292 and H1975 cells; however, combined treatment with low dose Ni and TNF- $\alpha$ significantly inhibited H292 and H1299 cell viability compared with H460 and H1299 cells by inducing cell apoptosis. NF- $\kappa \mathrm{B}$ protein expression and activity were also inhibited by the combination treatment. TNF- $\alpha$ treatment alone induced apoptosis in NF- $\mathrm{BB}$ deficient $\mathrm{H} 292$ and H1975 cells, similar to the effect of combination treatment
\end{abstract}

Correspondence to: Dr Ying Liu, Department of Thoracic Oncology, Cancer Hospital of Jilin Province, 1018 Huguang Road, Changchun, Jilin 130012, P.R. China

E-mail: liu_qi578@163.com

*Contributed equally

Key words: non-small cell lung cancer, nuclear factor- $\kappa \mathrm{B}$, tumor necrosis factor- $\alpha$, nimotuzumab, drug resistance in wild type H292 and H1975 cells. The results of the present study suggest that Ni sensitizes NSCLC cell lines to $\mathrm{TNF}-\alpha$-induced cell death by inhibiting $\mathrm{NF}-\kappa \mathrm{B}$ protein expression and activation, indicating a novel mechanism by which Ni suppresses the development of NSCLC.

\section{Introduction}

Lung cancer has been a common cause of cancer-associated mortality for several decades (1) and $\sim 85 \%$ of lung cancers are non-small cell lung cancer (NSCLC) (1). Current treatments for NSCLC include surgery, chemotherapy, target therapy and novel immune checkpoint blockades $(1,2)$. Epidermal growth factor receptor (EGFR) tyrosine kinase inhibitors are recommended for patients with NSCLC who have enhanced EGFR signal transduction (1). However, resistance to EGFR tyrosine kinase inhibitors occurs in a large proportion of patients with NSCLC, resulting in disease progression $(3,4)$.

Tumor necrosis factor (TNF)- $\alpha$, a $17-\mathrm{kDa}$ protein produced primarily by macrophages, is currently used in the regional treatment of locally advanced soft tissue sarcomas and metastatic melanomas (5). TNF- $\alpha$ functions via its receptors, TNF receptor (TNFR)-1 and TNFR-2 (5). TNFR-1 is widely expressed on the cell surface of most cells and is essential for the induction of cell apoptosis $(6,7)$. TNFR-2 expression is limited to certain neuronal, immune, hematopoietic and endothelial cells (8). Nuclear factor (NF) $-\kappa B$ has been demonstrated to be an essential transcription factor activated by TNF- $\alpha$ to prevent TNF- $\alpha$ and TNFR-1-mediated cell death (9). Inhibiting NF- $\kappa \mathrm{B}$ increases the sensitivity of NSCLC cells to apoptosis-inducing cancer therapies (10).

Overexpression and mutation of EGFR may lead to the constitutive activation of the EGF/EGFR signaling pathway and is associated with increased tumor proliferation and chemotherapy resistance (11). The EGF/EGFR signaling pathway also induces $\mathrm{NF}-\kappa \mathrm{B}$ activation (12-14). The results of these previous studies suggest that inhibiting the EGF signaling pathway may enhance TNF- $\alpha$-induced cell death in lung cancer. In the present study, the sensitivity of a number of NSCLC cell lines to TNF- $\alpha$ was investigated, as well as 
the effect of nimotuzumab (Ni) on NSCLC cell sensitivity to TNF- $\alpha$.

\section{Materials and methods}

Cell culture. Human NSCLC cell lines, H292 (Sigma-Aldrich; Merck KGaA, Darmstadt, Germany), H1299, H1975 and H460 (all American Type Culture Collection, Manassas, VA, USA) were cultured in RMPI-1640 medium supplemented with 10\% fetal bovine serum, $100 \mu \mathrm{g} / \mathrm{ml}$ streptomycin and $100 \mathrm{U} / \mathrm{ml}$ penicillin (all Thermo Fisher Scientific, Inc., Waltham, MA, USA) in a humidified incubator with at $37^{\circ} \mathrm{C}$ in an atmosphere containing $5 \% \mathrm{CO}_{2}$. Subculture was performed when the cells were $\sim 90 \%$ confluent.

Cell transfection. NF-кB knockdown in $\mathrm{H} 292$ and $\mathrm{H} 1975$ cells was performed using a NF- $\mathrm{BB}$ p65 short hairpin (sh) RNA lentivirus vector (Santa Cruz Biotechnology, Inc., Dallas, TX, USA) according to the manufacturer's protocol. Briefly, NF- $\kappa$ B p65 shRNA lentivirus vector (500 ng) or the control vector $(500 \mathrm{ng})$ was transfected into $10^{5}$ 293 cells by ViraPower ${ }^{\mathrm{TM}}$ Lentiviral Packaging Mix reagent (Thermo Fisher Scientific, Inc.) to produce the lentivirus. The harvested lentivirus particles were subsequently used to infect $\mathrm{H} 292$ and $\mathrm{H} 1975$ cells. Western blotting confirmed knockdown of NF- $\mathrm{BB}$ expression at $48 \mathrm{~h}$ following transfection.

Cell viability. An equal number of NSCLC cells $\left(5 \times 10^{3}\right.$ cells/well) was seeded in 96 -well plates. Treatments, including TNF- $\alpha(20,40$ or $80 \mathrm{ng} / \mathrm{ml})$ and $\mathrm{Ni}(1 \mathrm{mM}$ as the high dose or $0.5 \mathrm{mM}$ as the low dose) were administered at $37^{\circ} \mathrm{C} 24 \mathrm{~h}$ post seeding. Single treatment and combination treatment were used. In the combination treatment, $0.5 \mathrm{nM}$ $\mathrm{Ni}$ was used together with 20,40 or $80 \mathrm{ng} / \mathrm{ml}$ TNF- $\alpha$ to study the effects of Ni on TNF- $\alpha$ mediated cell death. Following the specified treatment time $(6,12,24,36$ or $48 \mathrm{~h})$, cell viability was measured by using a Cell Counting kit- 8 (CCK-8; Sigma-Aldrich; Merck KGaA). Briefly, $10 \mu$ l CCK-8 solution was added to each well and incubated for $30 \mathrm{~min}$ at $37^{\circ} \mathrm{C}$. Absorbance was measured at $450 \mathrm{~nm}$ using an $\mathrm{MRX}^{\circledR}$ II microplate reader (Dynex Technologies, Chantilly, VA, USA). The final cell viability was calculated as: [Treatment optical density (OD) value-blank OD value]/(control OD value-blank $\mathrm{OD}$ value). The cell viability was normalized to the control group at $0 \mathrm{~h}$ of treatment.

Western blotting. Western blotting was used to measure the expression of NF- $\kappa \mathrm{B}$ in NSCLC cell lines. Cells were harvested from cell culture and lysed using radioimmunoprecipitation buffer with proteinase inhibitor and phosphatase inhibitor (Thermo Fisher Scientific, Inc.). A bicinchoninic acid (BCA) assay was used to quantify proteins. Samples (30 $\mu \mathrm{g}$ total protein per lane) were separated by $4-20 \%$ SDS-PAGE and transferred to polyvinylidene difluoride membranes. Membranes were subsequently blocked in 5\% BSA-PBS buffer (at room temperature for $1 \mathrm{~h}$ ) and incubated with antibodies against anti-NF- $\mathrm{BB}(1: 1,500)$ with $\beta$-actin $(1: 2,000)$ as the internal control. Horseradish peroxidase (HRP)-conjugated secondary antibody (1:5,000 dilution) and electrochemiluminescence western blotting detection reagents (Pierce ECL Western Blotting substrate; Thermo Fisher Scientific, Inc.) were used for signal development. All antibodies were purchased from Abcam (Cambridge, MA, USA).

$N F-\kappa B$ activity assay. NF- $\mathrm{BB}$ activity was measured on $\mathrm{H} 460$, H1299, H292 and H1975 cells using the NF-kB p65 Transcription Factor Assay kit (ab133112; Abcam). Nuclear extraction was performed using the Nuclear Extraction kit (Abcam) according to the manufacturer's protocol. Briefly, the nuclear extracts containing activated transcription factor were added to the wells of the assay plate and incubated at room temperature for $1 \mathrm{~h}$. The transcription factor NFkB (p65) primary antibodies (from the kit; ab133112) were then added and incubated at room temperature for $1 \mathrm{~h}$. The HRP conjugated secondary antibodies (from the kit; ab133112) were subsequently added and incubated at room temperature for $1 \mathrm{~h}$. The substrate was then added and the plate was read at OD $450 \mathrm{~nm}$. The result was presented as the fold change vs. $\mathrm{H} 460$ cells.

Measurement of cleaved caspase-3 and poly ADP ribose polymerase (PARP). Levels of cleaved caspase-3 and cleaved PARP in the NSCLC cell lines were measured using ELISA. The human cleaved PARP1 ELISA kit (cat. no. ab174441; Abcam) and cleaved caspase-3 human ELISA kit (cat. no. KHO1091; Thermo Fisher Scientific, Inc.) were used according to the manufacturer's protocol. The total protein of each sample was quantified using a BCA protein assay.

Statistical analysis. All data are presented as the mean \pm standard deviation. Statistical analyses were performed using GraphPad Prism version 7 software (GraphPad Software, Inc., La Jolla, CA, USA). Statistical differences between the groups were analyzed by two-sample t-test (for two groups) or by one-way analysis of variance (for more than two groups) according to the group number. Tukey's multiple comparisons test was used to evaluate the difference of each group with every other group. $\mathrm{P}<0.05$ was considered to indicate a statistically significant difference. Two-tailed P-values were used to determine the statistical significance.

\section{Results}

$T N F-\alpha$ resistance varies between NSCLC cell lines. To explore the effect of TNF- $\alpha$ on NSCLC cells, four NSCLC cell lines were treated with 20,40 or $80 \mathrm{ng} / \mathrm{ml} \mathrm{TNF}-\alpha$ for $6-48 \mathrm{~h}$. No significant differences in cell viability were observed in $\mathrm{H} 292$ or H1975 cells treated with different concentrations of TNF- $\alpha$ (Fig. 1A and B). However, treatment with 40 or $80 \mathrm{ng} / \mathrm{ml}$ TNF- $\alpha$ significantly decreased the viability of H460 (Fig. 1C) and H1299 (Fig. 1D) cells (Fig. 1C and D). Treatment with $80 \mathrm{ng} / \mathrm{ml} \mathrm{TNF}-\alpha$ for 24 or $48 \mathrm{~h}$ caused a significant increase in the level of cleaved caspase-3 in H460 and H1299 cells, which suggests that TNF- $\alpha$ has an apoptosis-inducing effect (Fig. 1E and F). These results indicate the heterogeneous responses of NSCLC cells to TNF- $\alpha$.

Ni enhances TNF- $\alpha$ sensitivity in NSCLC cell lines. As TNF- $\alpha$ resistance was observed in certain NSCLC cell lines, the 
A

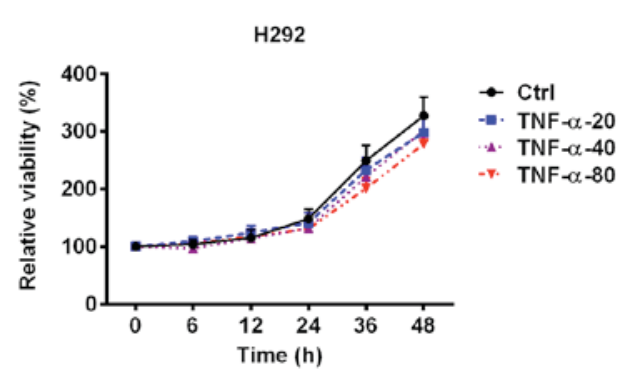

C

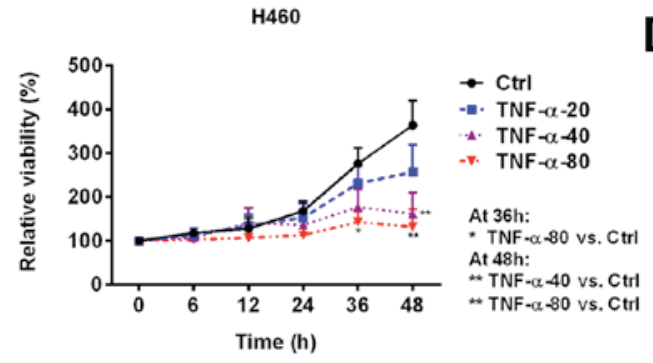

E

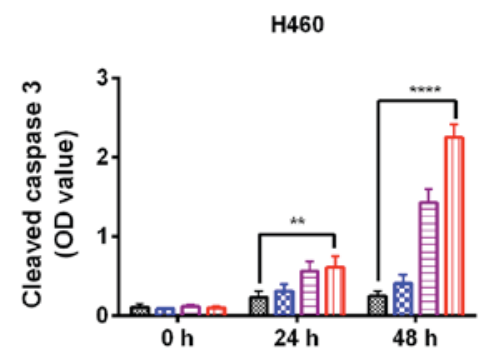

B

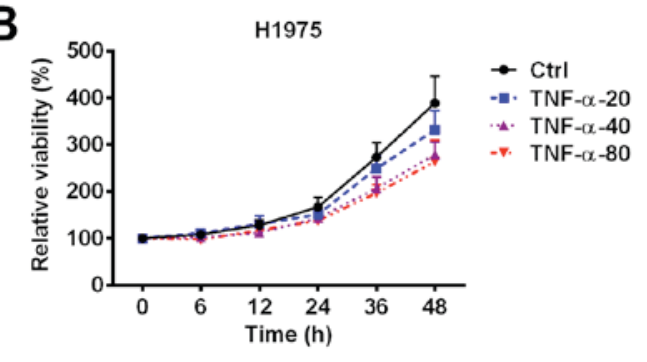

D

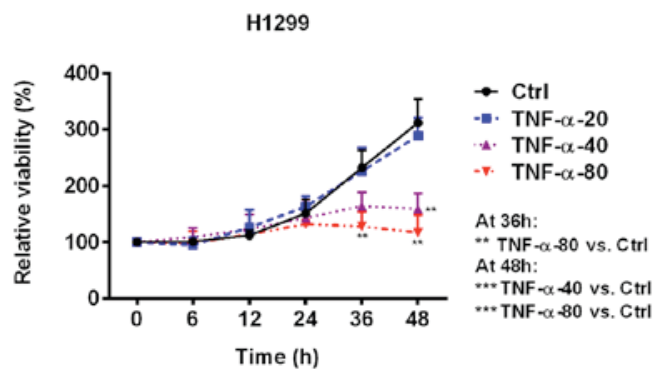

$\mathbf{F}$
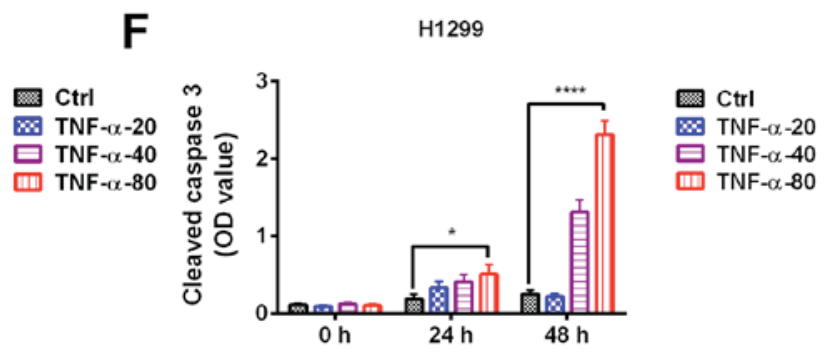

Figure 1. Sensitivity of non-small cell lung cancer cell lines to TNF- $\alpha$ treatment. (A) H292, (B) H1975, (C) H460, and (D) H1299 cell lines were treated with 20,40 , or $80 \mathrm{ng} / \mathrm{ml} \mathrm{TNF-} \alpha$ and cell viability was assessed. The cell viability was normalized to the control group at $0 \mathrm{~h}$. An increased level of cleaved caspase-3 was observed in (E) H460 and (F) H1299 cells following TNF- $\alpha$ treatment. ${ }^{*} \mathrm{P}<0.05,{ }^{* *} \mathrm{P}<0.01,{ }^{* * *} \mathrm{P}<0.001$ and ${ }^{* * * *} \mathrm{P}<0.0001$ vs. Ctrl. Ctrl, control; NSCLC, non-small cell lung cancer; TNF, tumor necrosis factor; OD, optical density.

possible mechanisms of the resistance were explored. H292 and H1975 cells expressed a notably higher level of EGFR compared with H1299 and H460 cells (Fig. 2A). In H292 and H1975 cells, low dose Ni treatment slightly inhibited cell viability and high dose Ni significantly inhibited cell viability (Fig. 2B and C). Low dose Ni combined with TNF- $\alpha$ was used to treat the H292 and H1975 cells. Low dose Ni ameliorated TNF- $\alpha$ resistance in $\mathrm{H} 292$ and $\mathrm{H} 1975$ cells, resulting in decreased cell viability at all TNF- $\alpha$ concentrations (Fig. 2D and $\mathrm{E}$ ). These results suggest that the EGFR signaling pathway is one of the mechanisms responsible for TNF- $\alpha$ resistance in H292 and H1975 cells.

Combined treatment with TNF- $\alpha$ and Ni stimulates apoptosis in NSCLC cell lines. To confirm the effect of TNF- $\alpha$ and low dose Ni combination treatment cleaved PARP and cleaved caspase- 3 were measured in $\mathrm{H} 292$ and H1975 cells. The results revealed that $\mathrm{TNF}-\alpha$ treatment caused no significant increase in cleaved PARP or caspase-3 (Fig. 3) However, combined treatment with TNF- $\alpha$ and low dose Ni significantly increased the levels of cleaved PARP and cleaved caspase-3 in H292 and H1975 cells at 48 and 24 h compared with the TNF- $\alpha$ only and control groups (Fig. 3). These results suggest that TNF- $\alpha$ and low dose Ni treatment work synergistically to induce apoptosis in H292 and H1975 cells.

Ni treatment inhibits $N F-\kappa B$ expression in NSCLC cell lines. To explore the mechanism by which $\mathrm{Ni}$ increases the efficacy of TNF- $\alpha$ treatment in $\mathrm{H} 292$ and $\mathrm{H} 1975$ cells, NF- $\mathrm{KB}$ protein expression was measured using western blotting and $\mathrm{NF}-\kappa \mathrm{B}$ activity was also determined. It was revealed that H460 and H1299 cells had comparable NF- $\mathrm{B}$ protein expression, whereas $\mathrm{NF}-\kappa \mathrm{B}$ protein expression was significantly increased in H292 and H1975 cells compared with H460 cells (Fig. 4A and $\mathrm{B}$ ). When subjected to $\mathrm{Ni}$ treatment, $\mathrm{NF}-\kappa \mathrm{B}$ protein expression was signifaicntly reduced in $\mathrm{H} 292$ and $\mathrm{H} 1975$ cells (Fig. 4A and B). The DNA binding activity of NF- $\kappa \mathrm{B}$ was significantly higher in H292 and H1975 cells compared with H460 cells (Fig. 4C). The Ni treatment significantly inhibited the DNA binding activity of NF- $\mathrm{BB}$ in $\mathrm{H} 292$ and H1975 cells (Fig. 4C). These results suggest that the EGFR signaling pathway regulates $\mathrm{NF}-\kappa \mathrm{B}$ in NSCLCs, which is a key transcriptional factor in the TNF- $\alpha$ response.

$N F-\kappa B$ deficiency reduces the NSCLC cell line resistance to $T N F-\alpha$. As Ni treatment was demonstrated to suppress $N F-\kappa B$ 


\section{A \\ H1299 H460 H1975 H292 \\ EGFR}

$\beta$-actin

B

H292

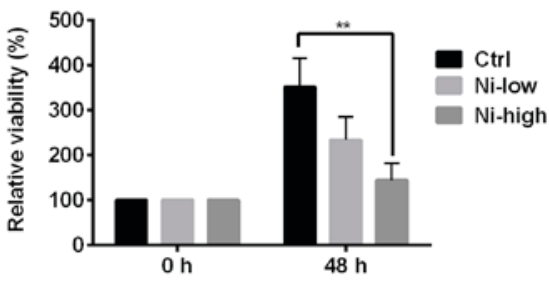

D

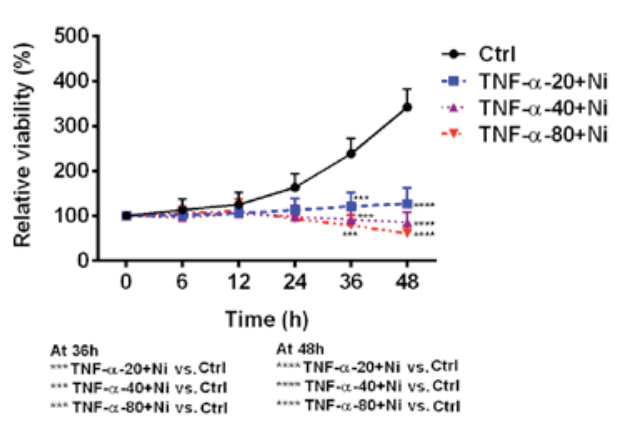

C

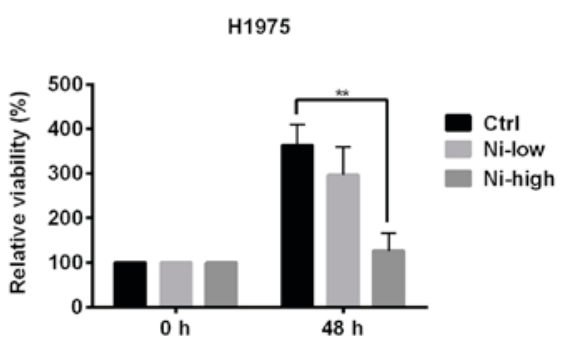

$\mathbf{E}$

H1975

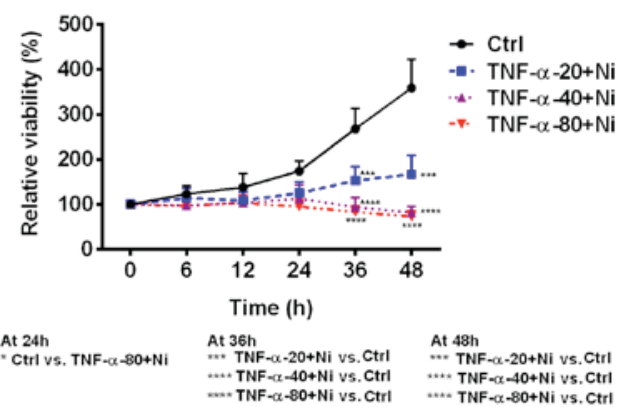

Figure 2. Effect of Ni on TNF- $\alpha$ resistant non-small cell lung cancer cell lines. (A) The expression of EGFR protein was measured in H460, H1299, H292 and H1975 cell lines. High dose (1 mM) Ni treatment significantly inhibited the viability of (B) H292 and (C) H1975 cells. A combination of low dose Ni treatment with TNF- $\alpha$ significantly suppressed the viability of (D) H292 and (E) H1975 cell lines. ${ }^{*} \mathrm{P}<0.05,{ }^{* *} \mathrm{P}<0.01,{ }^{* * * *} \mathrm{P}<0.001$ and ${ }^{* * * * *} \mathrm{P}<0.0001$ vs. the Ctrl. $\mathrm{Ni}$, nimotuzumab; TNF, tumor necrosis factor; EGFR, epidermal growth factor receptor; Ctrl, control.

A

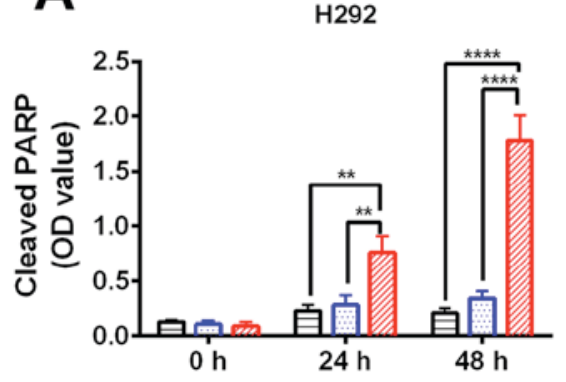

C

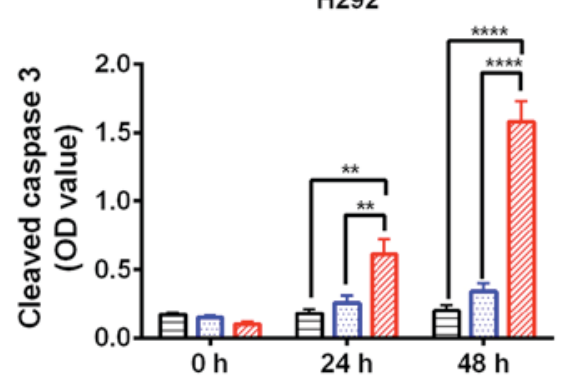

B

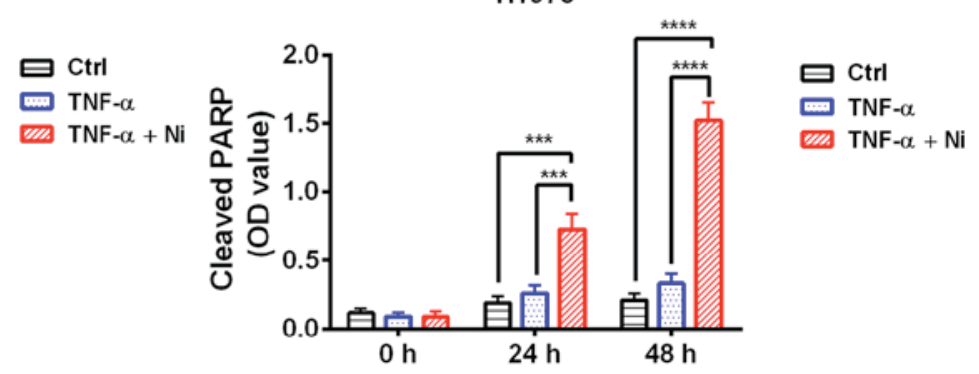

D
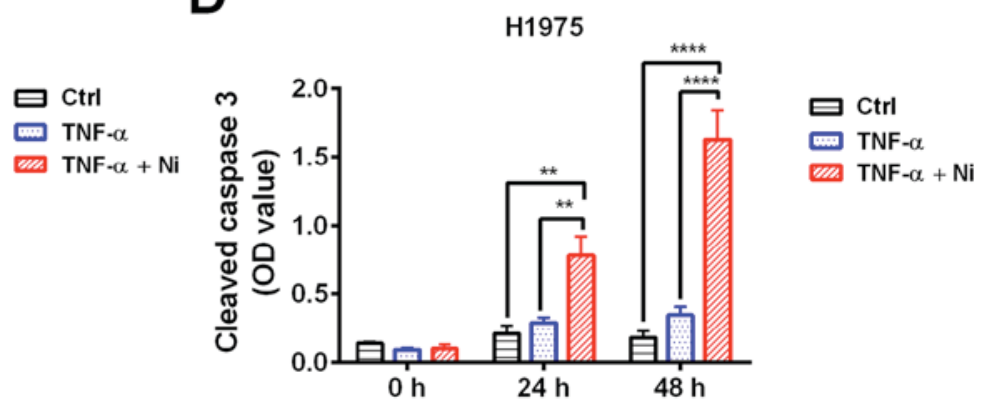

Figure 3. Combined treatment with TNF- $\alpha$ and Ni induces apoptosis in non-small cell lung cancer cell lines. Levels of cleaved PARP and cleaved caspase-3 in the non-small cell lung cancer cell lines H292 and H1975 treated with TNF- $\alpha$ with or without Ni were measured by ELISA. Cleaved PARP levels were significantly increased in the (A) H292 and (B) H1975 cells treated with Ni (0.5 mM) and TNF- $\alpha$ (40 ng/ml). Similarly, cleaved caspase-3 levels were significantly increased in (C) H292 and (D) H1975 cells following Ni and TNF- $\alpha$ treatment. ${ }^{* *} \mathrm{P}<0.01,{ }^{* * * *} \mathrm{P}<0.001$ and ${ }^{* * * * * *} \mathrm{P}<0.0001$. Ni, nimotuzumab; TNF, tumor necrosis factor; PARP, poly ADP ribose polymerase; OD, optical density; Ctrl, control. 


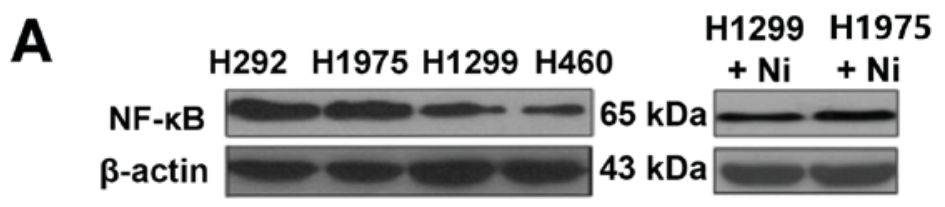

B

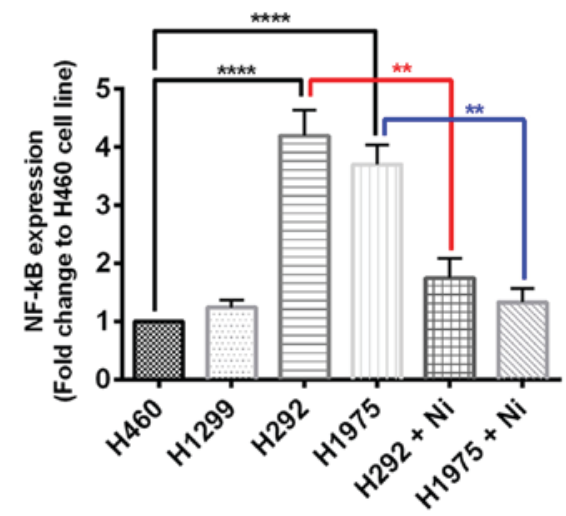

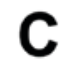

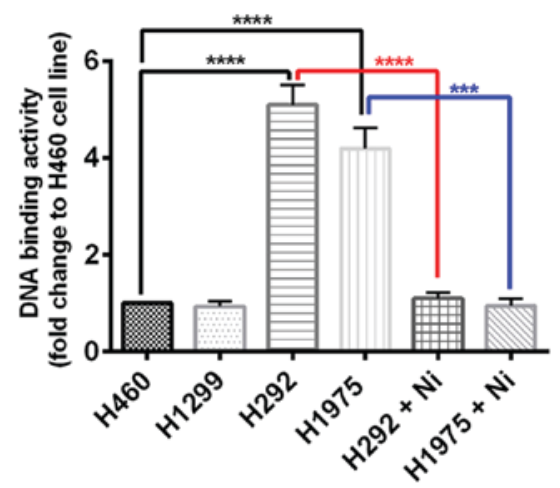

Figure 4. Ni treatment inhibits the protein expression and activity of NF- $\mathrm{KB}$ in non-small cell lung cancer cell lines. (A and B) The protein expression of NF- $\mathrm{kB}$ and (C) the DNA binding activity of NF-kB were measured in non-small cell lung cancer cell lines H460, H1299, H292 and H1975 treated with or without Ni. ${ }^{* *} \mathrm{P}<0.01,{ }^{* * *} \mathrm{P}<0.001$ and ${ }^{* * * *} \mathrm{P}<0.0001 . \mathrm{Ni}$, nimotuzumab; NF, nuclear factor.
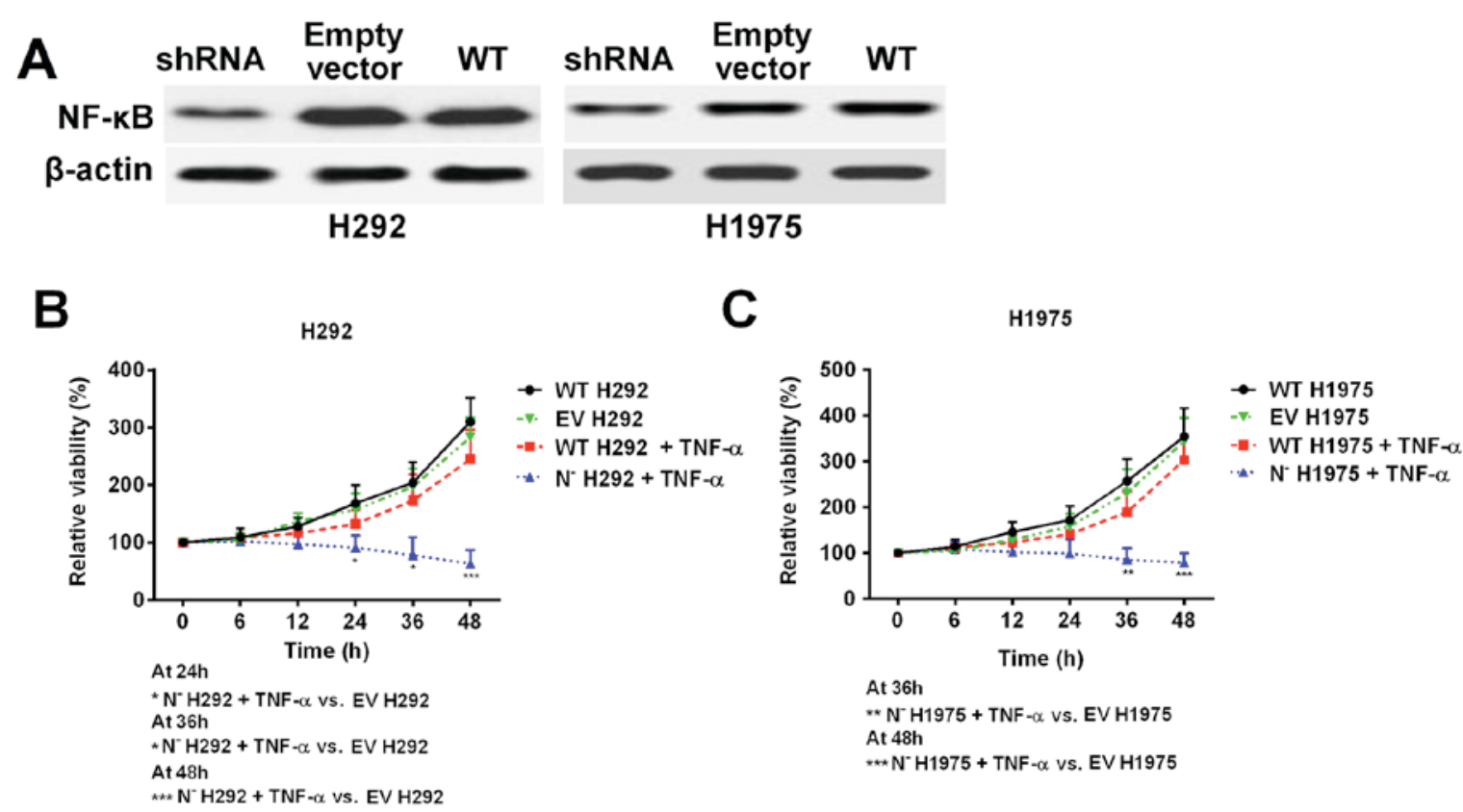

Figure 5. Knockdown of NF- $\mathrm{kB}$ by short hairpin RNA ameliorates resistance to TNF- $\alpha$ in non-small cell lung cancer cell lines. (A) NF- $\mathrm{kB}$ deficient H292 and H1975 cell lines were established. (B) The viability of $\mathrm{N}^{-} \mathrm{H} 292$ and (C) $\mathrm{N}^{-} \mathrm{H} 1975$ cells was significantly inhibited by TNF- $\alpha$ treatment (40 ng/ml) compared

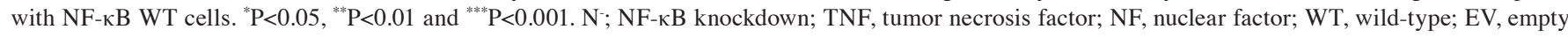
vector.

protein expression and activity, shRNA was used to knock down the expression of NF- $\mathrm{KB}$ in $\mathrm{H} 292$ and $\mathrm{H} 1975$ cell lines to mimic $\mathrm{Ni}$ treatment (Fig. 5A). The cell response to TNF- $\alpha$ treatment was subsequently investigated. Cell viability was significantly decreased in NF- $\mathrm{kB}$ deficient cells following TNF- $\alpha$ treatment, whereas the wild type cell lines remained resistant to TNF- $\alpha$ treatment (Fig. 5B and C). These results, together with the previous data, indicate that overexpression of NF- $\mathrm{\kappa B}$ in NSCLC cells with high EGFR signaling pathway activity is an important factor that contributes to TNF- $\alpha$ resistance.

\section{Discussion}

TNF- $\alpha$ is a multifunctional cytokine that is associated with a number of essential cellular processes, including regulating cell survival, apoptosis, inflammation and 
immune activity (2). The role of TNF- $\alpha$ in different types of cancer is varied and context dependent $(2,5,7,15)$. TNF- $\alpha$ may induce tumor cell death and has been used as a local treatment for advanced soft tissue sarcoma, melanoma and other unresectable tumors (5). Conversely, TNF- $\alpha$-mediated inflammation promotes tumor development and inhibition of TNF- $\alpha$ reduces tumor progression (15). Previous studies have suggested that $\mathrm{NF}-\kappa \mathrm{B}$ activation may be associated with resistance to TNF- $\alpha$-induced apoptosis in cancer cells $(16,17)$. The EGFR signaling pathway is critical in regulating $\mathrm{NF}-\kappa \mathrm{B}$ activation $(18,19)$. In the present study it was hypothesized that inhibiting the EGFR signaling pathway may sensitize NSCLC cells to TNF- $\alpha$ treatment by downregulating NF- $\kappa B$ activation.

In the present study it was demonstrated that NSCLC H460 and H1299 cell lines were sensitive to TNF- $\alpha$ treatment, whereas H292 and H1975 cell lines were resistant to TNF- $\alpha$ treatment, which suggests that TNF- $\alpha$ resistance is cell type dependent. It was observed that H292 and H1975 cells had increased levels of EGFR protein compared with H460 and H1299 cells. When combined with Ni, the TNF- $\alpha$-induced apoptosis of H292 and H1975 cells was increased. These results suggest that TNF- $\alpha$ resistance in NSCLC cells is associated with activation of the EGFR signaling pathway. A previous study demonstrated that TNF- $\alpha$ and EGF had similar effects on the activation of $\mathrm{NF}-\kappa \mathrm{B}(12) . \mathrm{NF}-\kappa \mathrm{B}$ is a key transcription factor that prevents TNF- $\alpha$ mediated cell death $(9,20)$, which may explain why $\mathrm{Ni}$ increased the sensitivity of NSCLC cells to TNF- $\alpha$-induced apoptosis.

To confirm that the EGFR signaling-induced activation of $N F-\kappa B$ is a major factor leading to TNF- $\alpha$ resistance, the effects of $\mathrm{Ni}$ on $\mathrm{NF}-\kappa \mathrm{B}$ activation were evaluated. $\mathrm{NF}-\kappa \mathrm{B}$ was highly expressed in $\mathrm{H} 292$ and $\mathrm{H} 1975$ cells, which also highly expressed EGFR. Ni treatment notably downregulated $\mathrm{NF}-\kappa \mathrm{B}$ expression in these cells. In the NF- $\kappa \mathrm{B}$ knockdown H292 and H1975 cells, TNF- $\alpha$ had significantly enhanced anti-tumor effects compared with the NF- $\kappa \mathrm{B}$ wild type cells. The results of the present study suggest that overactivation of $\mathrm{NF}-\kappa \mathrm{B}$ via EGFR overexpression is an important factor that mediates TNF- $\alpha$ resistance in NSCLC cells. These conclusions are in agreement with the results of previous studies, in which the activation of NF- $\mathrm{NB}$ enhanced NSCLC cell apoptosis (21).

Theenhanced expression of growth factors or overexpression of their receptors results in autonomously constitutive proliferation in a number of tumor types (22-25). Approximately $30 \%$ of patients with NSCLC exhibit increased EGFR mRNA expression (23). Targeting the EGFR signaling pathway using inhibitors, including $\mathrm{Ni}$, has been demonstrated to significantly improve patient survival rates $(26,27)$. However, the endogenous tumor inhibiting mechanisms, including TNF- $\alpha$ and its associated signaling pathways are also critical in controlling tumor development $(2,5)$. The present study demonstrated the potential of using EGFR inhibitors to sensitize NSCLC cells to TNF- $\alpha$, which is an endogenous anti-tumor factor found in the human body.

In conclusion, the results herein demonstrate that $\mathrm{Ni}$ increases the sensitivity of NSCLC cells to TNF- $\alpha$ induced cell death via inhibiting $\mathrm{NF}-\kappa \mathrm{B}$ expression and activation. The present study also revealed a novel mechanism by which $\mathrm{Ni}$ suppresses NSCLC development.

\section{Acknowledgements}

The authors would like to thank the Cancer Hospital of Jilin Province (Changchun, China) for their funding and support.

\section{References}

1. Reck M, Popat S, Reinmuth N, De Ruysscher D, Kerr KM and Peters S; ESMO Guidelines Working Group: Metastatic non-small-cell lung cancer (NSCLC): ESMO clinical practice guidelines for diagnosis, treatment and follow-up. Ann Oncol 25 (Suppl 3): iii27-iii39, 2014.

2. Wallach D: Cell death induction by TNF: A matter of self control. Trends Biochem Sci 22: 107-109, 1997.

3. Jackman D, Pao W, Riely GJ, Engelman JA, Kris MG, Jänne PA, Lynch T, Johnson BE and Miller VA: Clinical definition of acquired resistance to epidermal growth factor receptor tyrosine kinase inhibitors in non-small-cell lung cancer. J Clin Oncol 28: 357-360, 2010

4. Massarelli E, Varella-Garcia M, Tang X, Xavier AC, Ozburn NC, Liu DD, Bekele BN, Herbst RS and Wistuba II: KRAS mutation is an important predictor of resistance to therapy with epidermal growth factor receptor tyrosine kinase inhibitors in non-small-cell lung cancer. Clin Cancer Res 13: 2890-2896, 2007.

5. van Horssen R, Ten Hagen TL and Eggermont AM: TNF-alpha in cancer treatment: Molecular insights, antitumor effects, and clinical utility. Oncologist 11: 397-408, 2006.

6. Chen G and Goeddel DV: TNF-R1 signaling: A beautiful pathway. Science 296: 1634-1635, 2002.

7. Arnott CH, Scott KA, Moore RJ, Robinson SC, Thompson RG and Balkwill FR: Expression of both TNF-alpha receptor subtypes is essential for optimal skin tumour development. Oncogene 23: 1902-1910, 2004.

8. McCoy MK and Tansey MG: TNF signaling inhibition in the CNS: Implications for normal brain function and neurodegenerative disease. J Neuroinflammation 5: 45, 2008.

9. Beg AA and Baltimore D: An essential role for NF-kappaB in preventing TNF-alpha-induced cell death. Science 274: 782-784, 1996.

10. Jones DR, Broad RM, Madrid LV, Baldwin AS Jr and Mayo MW: Inhibition of NF-kappaB sensitizes non-small cell lung cancer cells to chemotherapy-induced apoptosis. Ann Thorac Surg 70: 930-937, 2000.

11. Mendelsohn J and Baselga J: The EGF receptor family as targets for cancer therapy. Oncogene 19: 6550-6565, 2000.

12. Sethi G, Ahn KS, Chaturvedi MM and Aggarwal BB: Epidermal growth factor (EGF) activates nuclear factor- $\kappa \mathrm{B}$ through $\mathrm{I} \kappa \mathrm{B} \alpha$ kinase-independent but EGF receptor-kinase dependent tyrosine 42 phosphorylation of IкB $\alpha$. Oncogene 34: 5407, 2015.

13. Biswas DK, Cruz AP, Gansberger E and Pardee AB: Epidermal growth factor-induced nuclear factor kappa B activation: A major pathway of cell-cycle progression in estrogen-receptor negative breast cancer cells. Proc Natl Acad Sci USA 97: 8542-8547, 2000.

14. Sun L and Carpenter G: Epidermal growth factor activation of NF-kappaB is mediated through IkappaBalpha degradation and intracellular free calcium. Oncogene 16: 2095-2102, 1998.

15. Zhao X, Fan W, Xu Z, Chen H, He Y, Yang G, Yang G, Hu H, Tang S, Wang P, et al: Inhibiting tumor necrosis factor-alpha diminishes desmoplasia and inflammation to overcome chemoresistance in pancreatic ductal adenocarcinoma. Oncotarget 7: 81110-81122, 2016.

16. Wang CY, Mayo MW and Baldwin AS Jr: TNF- and cancer therapy-induced apoptosis: Potentiation by inhibition of NF-kappaB. Science 274: 784-787, 1996.

17. Kim JY, Lee S, Hwangbo B, Lee CT, Kim YW, Han SK, Shim YS and Yoo CG: NF-kappaB activation is related to the resistance of lung cancer cells to TNF-alpha-induced apoptosis. Biochem Biophys Res Commun 273: 140-146, 2000.

18. Tanaka K, Babic I, Nathanson D, Akhavan D, Guo D, Gini B, Dang J, Zhu S, Yang H, De Jesus J, et al: Oncogenic EGFR signaling activates an mTORC2-NF- $\mathrm{kB}$ pathway that promotes chemotherapy resistance. Cancer Discov 1: 524-538, 2011. 
19. Lin Y, Bai L, Chen W and Xu S: The NF-kappaB activation pathways, emerging molecular targets for cancer prevention and therapy. Expert Opin Ther Targets 14: 45-55, 2010

20. Delhalle S, Deregowski V, Benoit V, Merville MP and Bours V: NF-kappaB-dependent MnSOD expression protects adenocarcinoma cells from TNF-alpha-induced apoptosis. Oncogene 21: 3917-3924, 2002.

21. Song L, Xiong H, Li J, Liao W, Wang L, Wu J and Li M Sphingosine kinase-1 enhances resistance to apoptosis through activation of $\mathrm{PI} 3 \mathrm{~K} / \mathrm{Akt} / \mathrm{NF}-\kappa \mathrm{B}$ pathway in human non-small cell lung cancer. Clin Cancer Res 17: 1839-1849, 2011.

22. Nicholson RI, Gee JM and Harper ME: EGFR and cancer prognosis. Eur J Cancer 37 (Suppl 4): S9-S15, 2001.

23. Brabender J, Danenberg KD, Metzger R, Schneider PM, Park J, Salonga D, Hölscher AH and Danenberg PV: Epidermal growth factor receptor and HER2-neu mRNA expression in non-small cell lung cancer is correlated with survival. Clin Cancer Res 7: $1850-1855,2001$

24. Repetto L, Gianni W, Aglianò AM and Gazzaniga P: Impact of EGFR expression on colorectal cancer patient prognosis and survival: A response. Ann Oncol 16: 1557, 2005.
25. Bhargava R, Gerald WL, Li AR, Pan Q, Lal P, Ladanyi M and Chen B: EGFR gene amplification in breast cancer: Correlation with epidermal growth factor receptor mRNA and protein expression and HER-2 status and absence of EGFR-activating mutations. Mod Pathol 18: 1027-1033, 2005.

26. Reddy BK, Lokesh V, Vidyasagar MS, Shenoy K, Babu KG, Shenoy A, Naveen T, Joseph B, Bonanthaya R, Nanjundappa, et al: Nimotuzumab provides survival benefit to patients with inoperable advanced squamous cell carcinoma of the head and neck: A randomized, open-label, phase IIb, 5-year study in Indian patients. Oral Oncol 50: 498-505, 2014.

27. Cabanas R, Saurez G, Rios M, Alert J, Reyes A, Valdes J, Gonzalez MC, Pedrayes JL, Avila M, Herrera R, et al: Treatment of children with high grade glioma with nimotuzumab: A 5-year institutional experience. MAbs 5: 202-207, 2013.

This work is licensed under a Creative Commons Attribution-NonCommercial-NoDerivatives 4.0 International (CC BY-NC-ND 4.0) License. 